\title{
Retrospective Documentation of a Confirmed White-Lipped Green Pit Viper (Trimeresurus albolabris Gray, 1842) Bite in the South-Central Hills of Nepal
}

\author{
Deb P. Pandey, $\mathrm{PhD}^{1,2,3}$; Amod Ghimire, $\mathrm{MBBS}^{4}$; Bhola R. Shrestha, $\mathrm{MD}^{5}$ \\ ${ }^{1}$ South Asian Clinical Toxicology Research Collaboration, Faculty of Medicine, University of Peradeniya, Peradeniya, Sri Lanka; ${ }^{2}$ School of \\ Medicine and Public Health, Faculty of Health and Medicine, University of Newcastle, Newcastle, Australia; ${ }^{3}$ Department of Veterinary \\ Microbiology and Parasitology, Agriculture and Forest University, Rampur, Chitwan, Nepal; ${ }^{4}$ Patan Academy of Health Sciences, Kathmandu, \\ Nepal; ${ }^{5}$ National Academy of Medical Sciences, Bir Hospital, Kathmandu, Nepal
}

\begin{abstract}
This case report documents envenomation by an arboreal white-lipped green pit viper (Trimeresurus albolabris), a species found in South and Southeast Asia that causes the majority of venomous snakebites among Southeast Asian pit vipers. Clinical features vary from asymptomatic to serious coagulopathy that may progress into life-threatening or fatal hemorrhage. The proven life-threatening cases described in published literature, however, are sparse. Practically, no specific antivenom targeted to pit viper bites is available in Nepal. We report a case (managed with several non-evidence-based interventions) of noticeable coagulopathic envenomation due to confirmed $T$ albolabris bite in Nepal. This is the first known reported case of such a bite in Nepal. This case highlights the urgent need to improve diagnosis, monitoring, and supportive care for bite victims and to study the effectiveness of Thai pit viper antivenoms for the treatment of T albolabris envenomations.
\end{abstract}

Keywords: snakebite, envenomation, hemotoxicity, antivenom, coagulopathy, venom-induced consumption coagulopathy

\section{Introduction}

Clinical coagulopathy due to pit viper (Trimeresurus species) bites is a common systemic envenomation in Asia. $^{1-7}$ The genus Trimeresurus comprises approximately 46 pit viper species. ${ }^{8}$ Little is known about the pit viper species diversity and the burden and effects of bite envenomations. Among the 6 pit viper species with definitive distribution records in Nepal (ie, Gloydius himalayanus, Ovophis monticola, Trimeresurus albolabris, septentrionalis, stejnegeri, and tibetanus), albolabris (synonym Cryptelytrops albolabris) is a common, medically relevant snake that is distributed in the lowlands, hills, and lower ranges in mountains of Nepal..$^{9-19}$ T albolabris is also distributed in South and Southeast Asian countries, ${ }^{20,21}$ where they can cause local and systemic

Corresponding author: Deb P. Pandey, PhD, Department of Veterinary Microbiology and Parasitology, Agriculture and Forest University, Rampur, Chitwan, Nepal; e-mail: debpandey@gmail.com.

Submitted for publication May 2018.

Accepted for publication November 2018. envenomation ${ }^{2,22-25}$ producing painful local swelling, blister formation, necrosis, and coagulopathy.,26-28 Fatalities have probably occurred either primarily or secondarily after T albolabris envenomation in Hong Kong ${ }^{24}$ and Java. ${ }^{26}$ In Nepal, at least 3 to $8 \%$ of snakebites are attributed to $T$ albolabris. ${ }^{14,17,19,29,30}$ Despite this, there are no published details on systemic envenomation by pit vipers. Herein, we present clinical manifestations and management practices for a proven $T$ albolabris envenomation that occurred in the south-central hills of Nepal. This is the first known reported case of such a bite in Nepal. This case was treated with several non-evidencebased interventions without use of antivenom, potentially making it of additional interest.

\section{Case report}

A 17-y-old, relatively healthy boy from Bharatpur Metropolitan City in Nepal was bitten by a $T$ albolabris (Figure 1) at 1845 while rescuing the snake, which was resting in a bamboo bush in Gorkha District in the southcentral hills of Nepal. The snake that inflicted the 


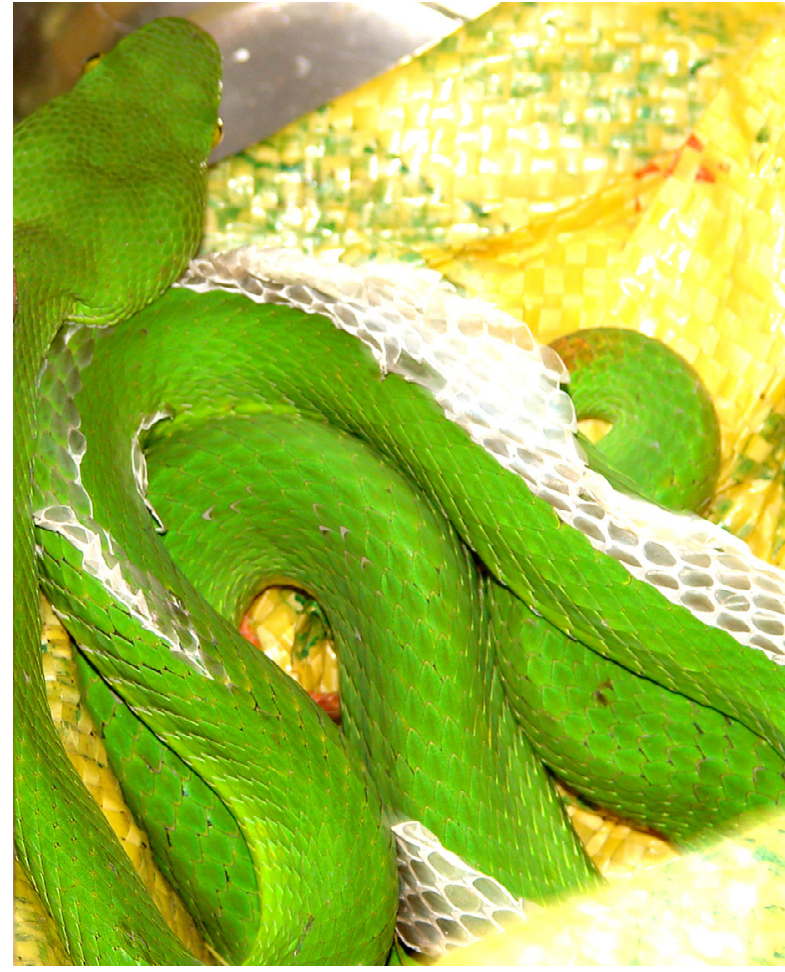

Figure 1. White-lipped green pit viper (Trimeresurus albolabris) involved in bite while rescuing it from premises of an herbal company in Gorkha District, Nepal. Photograph by Deb P. Pandey.

envenomation was formally identified by the senior author (DPP) with the keys included in widely used herpetological guidebooks. ${ }^{31,32}$ The victim was bitten on the lateral aspect of his left wrist (Figure 2) while attempting to pick up the snake with his bare hands. He applied a handkerchief to the bite site as a loose ligature (Figure 2). Then he was carried up the road for $25 \mathrm{~min}$ and transferred to a bus, which carried him in Laxmi Hospital in Tanahu District, where he arrived $1.5 \mathrm{~h}$ after the bite. While riding the bus, he used his own sacred thread Janai as an arm sling on the bus and kept his hand below heart level until he reached the hospital.

On admission to the hospital there were 2 distinct fang marks with local bleeding from the bite site and swelling of the wrist, back of the hand, and fingers. About $4.5 \mathrm{~h}$ postbite, the swelling extended up the forearm to the elbow (Figure 3). He was treated with antibiotics and a proteolytic enzyme (Table 1). Because of the extension of swelling, he was referred to the Bharatpur Hospital, Chitwan, about $36 \mathrm{~h}$ after snakebite (0645). He was referred for surgical consultation at a higher center immediately after initial evaluation in the emergency department of Bharatpur Hospital (1145).

The patient was admitted in College of Medical Sciences, Chitwan, at 1215 (41.5 h after snakebite). On
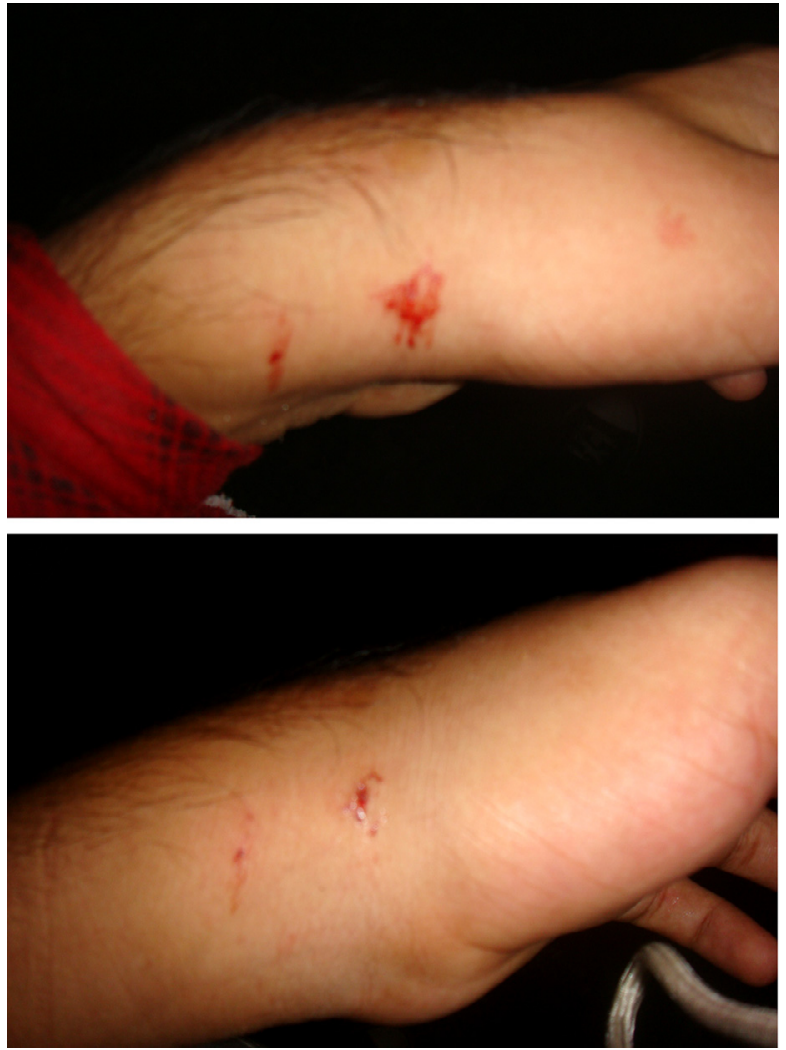

Figure 2. White-lipped green pit viper (Trimeresurus albolabris) bite on lateral aspect of the left hand. Top, immediately after bite, red piece of cloth is a loose tourniquet. Bottom, after reaching to local hospital. Photograph by Amod Ghimire.

examination, there was extensive swelling of the left upper limb up to the left upper part of the chest. Initial laboratory values are described in Table 1 . His prothrombin time (PT) remained prolonged on subsequent testing in the fourth, sixth, and seventh days after snakebite. Platelet counts were not performed until 1 wk postenvenomation. Kidney function tests were not performed.

After admission ( $41.5 \mathrm{~h}$ after snakebite), he received ongoing antibiotic therapy, histamine receptor antagonist (ranitidine, $150 \mathrm{mg}$ orally, twice daily), nonsteroidal anti-inflammatory drug (ibuprofen, $400 \mathrm{mg}$ orally, thrice daily), and vitamins (Table 1). Two units of fresh frozen plasma (FFP) were transfused on the sixth day after snakebite.

The swelling gradually subsided, and the patient was discharged on request on the seventh day after the snakebite. He was advised to take similar medicines (Table 1), have the PT tested every alternate day, and return for follow-up.

He returned to the hospital for a follow-up visit on the ninth day after snakebite. His PT had decreased to $38 \mathrm{~s}$ and his medications were discontinued. Antivenom was 


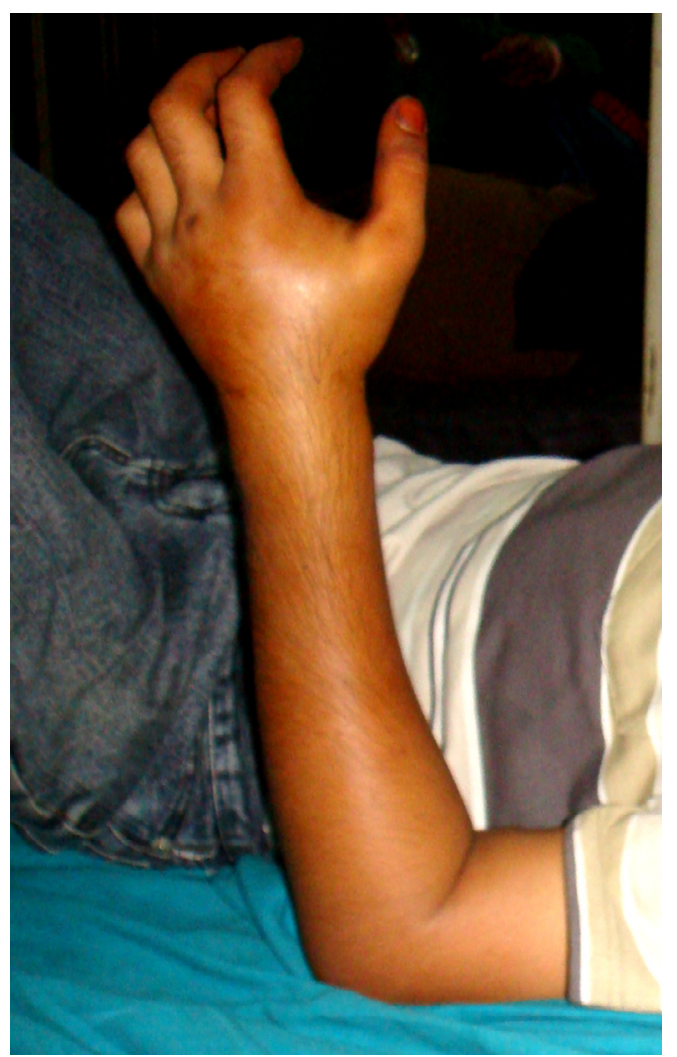

Figure 3. Swelling shown extending up the forearm to the elbow of the left hand. Healthcare staff cleaned the bite site and dipped the hand in a concentrated potassium permanganate solution that caused erythema-like features on hand. Photograph by Chandra P. Adhikari.

not given to this patient at either hospital. He reported no sequelae of the bite.

\section{Discussion}

We report a case of prolonged coagulopathy due to a confirmed bite by $T$ albolabris in Nepal.

The patient did not develop any systemic bleeding manifestations. Bleeding was only from the bite site with the normal bleeding time and normal whole blood clotting test (WBCT) at about $42 \mathrm{~h}$ postbite. This was seen despite the risk of systemic bleeding due to thrombinlike compounds in $T$ albolabris venom. ${ }^{33}$ Two cases of envenomation from this species in Thailand ${ }^{34}$ and 1 from Hong Kong ${ }^{22}$ involved severe systemic bleeding. A study in Thailand described $54 \%$ of cases $(n=13)$ with incoagulable blood and $17 \%(\mathrm{n}=4)$ with systemic bleeding among 24 cases envenomed by $T$ albolabris. ${ }^{2}$ Others have described $T$ albolabris as having the potential to cause consumption coagulopathy. ${ }^{35}$ The risk of systemic bleeding is even greater without the provision of antivenom. Despite the risk of systemic bleeding, this patient did not undergo sufficient investigations to assess the possible evolution of systemic coagulopathy. Although thrombocytopenia is a common hematological effect and a hallmark of hematological disorders due to pit viper envenomation, ${ }^{23,36-38}$ platelets were only measured in a single assay that detected mild thrombocytopenia (Table 1). For the proper diagnosis of pit viper bite, platelets should be measured on arrival and serially monitored including for a week or more postdischarge.

The prolonged PT from $41.5 \mathrm{~h}$ postbite to the ninth day postbite (Table 1) indicated moderate to severe local envenomation (with mild systemic involvement) due to mild depletion of the fibrinogen resulting in mild consumption coagulopathy. ${ }^{7}$ The prolonged PT was described as occurring in the majority of green pit viper bite cases ${ }^{36}$ in 1 report and in a single case of suspected pit viper bite. ${ }^{39}$ Nevertheless, the reports of defibrination syndrome (ie, hypofibrinogenemia) due to T albolabris bite elsewhere ${ }^{2,3,22,24,40}$ supported our diagnosis of mild consumption coagulopathy, indicating the risk for life-threatening hemorrhage., ${ }^{24}$ Because the WBCT20 has notably variable sensitivity and specificity, ${ }^{41}$ the information on conditions in which the assay was run, including the type of tube used, should be provided to better evaluate the profile of efficiency of WBCT. Whenever possible, it is important to run a control sample in parallel using a blood sample drawn from a healthy volunteer.

In addition to coagulopathy, local effects such as intense pain locally and extension of swelling proximally up to the left upper part of the chest in our case were also reported in other cases in parts of Nepal, Bangladesh, Hong Kong, and Thailand ${ }^{2,4,22,26-28,37,39}$ and in the United States (an exotic neonatal $T$ albolabris envenomation). ${ }^{42}$ Venom phospholipases A2 and metalloproteases are probably responsible for the local edema that, without treatment, can progress to local blistering and necrosis. ${ }^{2,43}$ The intense swelling and pain experienced by our patient was not associated with the loose ligature (Figure 2), which was used for about 30 min only. In an attempt to reduce the extensive swelling of the bitten part, a non-evidence-based intervention (ie, administration of proteolytic enzyme and antibiotics of doubtful benefit) was used with this patient. There is no evidence supporting this intervention, and it may do harm; therefore, it is contraindicated.

Although bacterial infection may be primary (snake venom and the snake buccal cavity contain bacterial flora) ${ }^{25,44}$ or secondary (affecting necrotic wounds $s^{45-47}$ that sometimes develop after pit viper envenomations), antibiotics are not routinely used prophylactically. ${ }^{48,49}$ However, any signs of evolving infection should prompt broad-spectrum antibiotic treatment. Distinguishing infection from venom-induced local effects can be quite 
Table 1. Timing, laboratory findings, and management for Trimeresurus albolabris bite case in Nepal

\begin{tabular}{|c|c|c|}
\hline Timing & Laboratory findings & Details of management (medication) \\
\hline $1.5 \mathrm{~h}$ after snakebite & None & $\begin{array}{l}\text { Healthcare staff cleaned the bite site and advised } \\
\text { the patient to dip his hand in a concentrated } \\
\text { potassium permanganate solution and remove } \\
\text { the ligature and thread-sling. The patient was } \\
\text { advised to keep his hand below heart level using } \\
\text { a cotton sling. }\end{array}$ \\
\hline About $4.5 \mathrm{~h}$ after snakebite & None & $\begin{array}{l}\text { He was treated with ampicillin } 500 \mathrm{mg} \text {, IV and } \\
\text { cloxacillin } 500 \mathrm{mg} \text {, IV (ie, megapen IV, } 1 \mathrm{~g} \text {, } \\
\text { stat; and twice a day); trypsin-chymotrypsin } \\
10 \mathrm{mg} \text {, PO (chymoral forte, PO, thrice a day); } \\
\text { dextrose } 5 \% \text { II unit, IV ( } 500 \mathrm{~mL} \text { in each unit, } \\
\text { over } 24 \mathrm{~h} \text { ). }\end{array}$ \\
\hline $41.5 \mathrm{~h}$ after snakebite & $\begin{array}{l}\text { Initial laboratory investigations included } \\
\text { white cell count of } 10 \times 10^{9} / \mathrm{L}(\mathrm{RR} \text { : } \\
\left.4-11 \times 10^{9} / \mathrm{L}\right) \text {, neutrophils } 79 \%(\mathrm{RR} \text { : } \\
\text { 40-65), lymphocytes } 17 \% \text { (range: } \\
\text { 20-45), otherwise normal differential } \\
\text { count, and erythrocyte sedimentation rate } \\
\text { was } 2 \text { mm in first hour (RR: } 1-10 \mathrm{~mm}) \text {. } \\
\text { His coagulation studies were a bleeding } \\
\text { time (Ivy's method) of } 3 \text { min (RR: } 2-7 \\
\text { min), whole blood clotting time (Lee- } \\
\text { White WBCT method), } 6 \text { min } 30 \mathrm{~s}(\mathrm{RR}: \\
3-8 \text { min), and PT of greater than } 2 \text { min } \\
\text { (control } 14 \mathrm{~s} \text { [RR: } 12-16 \mathrm{~s}) \text {. }\end{array}$ & $\begin{array}{l}\text { He received ongoing antibiotic therapy with } \\
\text { ampicillin } 250 \mathrm{mg}, \mathrm{IV} \text { and cloxacillin } 250 \mathrm{mg} \text {, } \\
\text { IV (megapen } 500 \mathrm{mg}, \mathrm{IV}, 4 \text { times daily for } 4 \mathrm{~d} \text { ); } \\
\text { gentamicin } 160 \mathrm{mg} \text {, IV, once a day for } 4 \mathrm{~d} \text { in } \\
\text { addition to metronidazole } 500 \mathrm{mg}, \mathrm{IV}, 3 \text { times a } \\
\text { day for } 4 \mathrm{~d} \text {; ranitidine, PO (Aciloc } 150 \mathrm{mg}, \mathrm{PO} \text {, } \\
2 \text { times a day); Flexon, PO (ibuprofen } 400 \mathrm{mg} \\
\text { and paracetamol } 500 \mathrm{mg} \text { ), orally, } 3 \text { times a } \\
\text { day); prednisolone, PO (wysolone } 10 \mathrm{mg}, \mathrm{PO} \text {, } \\
3 \text { times a day for } 4 \mathrm{~d} \text { ); and neurobion, PO (vita- } \\
\text { min B1, B6, and B12), } 1 \text { tab once a day for } 2 \mathrm{~d} \text { ). } \\
\text { He was also given vitamin K (10 mg, intramus- } \\
\text { cularly, once a day for } 5 \mathrm{~d} \text { ). }\end{array}$ \\
\hline Fourth post-snakebite day & $\begin{array}{l}\text { PT on } 2 \text { different occasions more than } \\
1 \mathrm{~min} \text {. }\end{array}$ & None \\
\hline Fifth post-snakebite day & None. & None \\
\hline Sixth post-snakebite day & PT more than 2 min. & Two units of fresh frozen plasma were transfused. \\
\hline Seventh post-snakebite day & $\begin{array}{l}\text { PT } 56 \text { s; platelet count was } 165 \times 10^{9} / \mathrm{L} \\
\quad\left(\text { RR: } 150-400 \times 10^{9} / \mathrm{L}\right)\end{array}$ & $\begin{array}{l}\text { The patients was discharged on request with the } \\
\text { following advice: 1) amoxycillin } 250 \mathrm{mg} \text { and } \\
\text { flucloxacillin } 250 \mathrm{mg} \text {, PO (ie, capsule megapen } \\
500 \mathrm{mg} \text { PO, } 4 \text { times a day for } 3 \mathrm{~d} \text { ); } 2 \text { ) metroni- } \\
\text { dazole, PO, } 400 \mathrm{mg}, 3 \text { times a day for } 3 \mathrm{~d} \text {; } 3 \text { ) } \\
\text { ranitidine, PO (Aciloc } 150 \mathrm{mg}, \mathrm{PO} \text {, twice a day } \\
\text { for } 2 \mathrm{~d} \text {; 4) flexon, PO (ibuprofen } 400 \mathrm{mg} \text { and } \\
\text { paracetamol } 500 \mathrm{mg} \text { ), PO, } 3 \text { times a day for } 2 \mathrm{~d} \text {, } \\
\text { then as per required (SOS); 5) neurobion (vita- } \\
\text { min B1, B6, and B12), } 1 \text { tab, PO, once a day for } \\
1 \text { week; and 6) PT measurement every alternate } \\
\text { day. He was asked to follow up with the report. }\end{array}$ \\
\hline Ninth post-snakebite day & His PT had decreased to $38 \mathrm{~s}$. & Medications were discontinued. \\
\hline
\end{tabular}

IV, intravenous; PT, prothrombin time; RR, reference range; PO, by mouth

difficult and requires careful evaluation. Pre-emptive use of antibiotics without clear clinical and laboratory evidence is not warranted, but we recommend using tetanus prophylaxis as soon as any coagulopathy has been corrected. $^{25,47}$

The use of FFP in treating envenomated patients with consumptive coagulopathy who have not received antivenom may prolong the coagulopathy and increase the risk of hemorrhage. ${ }^{35}$ Although swelling gradually reduced after the administration of 2 units of FFP in our case, PT was noticeably prolonged (Table 1). This has been reported previously in Hong Kong. ${ }^{22}$ FFP supplies clotting factors such as fibrinogens that can be activated by the circulating venom toxins and those toxins absorbed by the uptake of additional venom possibly sequestered at the bite site. ${ }^{50,51} \mathrm{~A}$ recently conducted 
clinical trial investigating envenomed patients with consumptive coagulopathy ${ }^{52}$ suggested that using FFP and antivenom together restored clotting factors more rapidly and reduced clotting time and the amount of antivenom required. FFP was found not to expedite reversal of coagulopathy in patients envenomed by Russell's viper (Daboia russelii) in Sri Lanka. ${ }^{53}$ Because there is no consistent quality evidence supporting provision of FFP even with antivenom, ${ }^{50,53}$ FFP should not be transfused except for clearly defined clinical indications. Otherwise, it may complicate treatment, resulting in prolonged hospital stay and higher treatment costs.

Overall, $T$ albolabris envenomation should be treated with proper antivenom ${ }^{51}$ available in Thailand ${ }^{54}$ in addition to appropriate supportive care and wound management. Envenomation by this species should be considered serious because it can result not only in mild local effects but also in severe consumptive coagulopathy, placing the patient at the risk of systemic bleeding and death. There is no pit viper antivenom available in Nepal. ${ }^{54}$ The administration of Thai green pit viper antivenom has been shown to reduce severe limb edema, reverse coagulopathy in patients envenomed by pit viper, and neutralize venoms from different pit viper species distributed in Asia. ${ }^{27,39,42,43,55,56}$ It is important to know the effectiveness of Thai green pit viper antivenom against Nepalese pit viper envenomations in speeding recovery. The Nepal government should plan to use Thai hematopolyvalent antivenom if it cross-neutralizes venoms from Nepalese green pit vipers ${ }^{39,57}$ or develop antivenom that covers all Asian pit vipers distributed in Nepal.

In our case, ranitidine was used to reduce the stressinduced hypersecretion of gastric acid despite no administration of antivenom. There is no evidence to support the administration of vitamin B complex or vitamin $\mathrm{K}$ for envenomation, and the latter may introduce risk. There is also no evidence for any benefit of using prednisolone ${ }^{58}$ in the treatment of envenomation, aside from its value in preventing serum sickness after the administration of some antivenoms. This is not applicable in our case because no antivenom was administered. Analgesia (nonsteroidal anti-inflammatory medicine [eg, ibuprofen]) can be given to patients without contraindications, given normal renal and coagulation function. ${ }^{42}$ Because our patient had unknown renal function and coagulopathy was not serially monitored, the use of ibuprofen was inappropriate. Kidney injury is possible after envenomation by many viperid species. ${ }^{34,59,60}$ Renal function should be monitored periodically to ensure appropriate supportive care.

The patient used nonstandard first aid measures due to limited knowledge on prehospital care of snakebites. ${ }^{61}$
Although controversial when used for viperid envenomation, we support the use of the local compression pad immobilization method $^{62}$ to confine the venom to the affected extremity and reduce systemic absorption. We recommend keeping the bitten body part elevated in all pit viper envenomations to reduce local swelling and minimize local tissue damage. ${ }^{63}$ Patients should also be transported quickly to receive proper medical care.

\section{Conclusion}

White-lipped green pit viper ( $T$ albolabris) envenomation may be life-threatening in Nepal because of no availability of pit viper antivenom, poor diagnosis and monitoring of the patient, use of non-evidence-based interventions (eg, use of FFP, proteolytic enzymes, antibiotics), and poor knowledge of prehospital care of snakebite. There is a clear need for an evidenceinformed, unified algorithm and research on the effectiveness of Thai green pit viper antivenoms for the treatment of pit viper bites in Nepal. Additional clinical and laboratory studies of confirmed pit viper bite are important for proper evaluation. For the proper diagnosis and management of coagulation disorder due to pit viper envenomation, platelet count, bleeding time, PT, activated partial thromboplastin time, thrombin time, plasminogen, fibrinogen, fibrin degradation product, D-dimer level, soluble fibrin monomer, euglobulin clot lysis time, and renal and liver function should all be measured regularly (with special consideration of the risk of bleeding at the site of blood sampling) until normality is restored. This helps to determine venom-induced consumptive coagulopathy and to provide proper supportive care. Snakebite management guidelines in Nepal could be improved by adopting judicious supportive care and pit viper antivenom therapy.

Acknowledgment: The authors thank the hospitals involved for providing treatment details and laboratory reports. They also thank a German volunteer in Nepal who initially carried the patient in the evacuation to local hospital. Moreover, they are grateful to Chandra Prasad Adhikari for the due care of the snakebite victim. They thank Geoff K. Isbister, Clinical Toxicology Research Group, University of Newcastle, Australia, for his initial review of this article and anonymous reviewers for their critical review comments. Written consent for publication of this case history and photographs was obtained from the patient.

Author Contributions: Conceived the study during which the case was recorded, identified the snake, and collected primary data (DPP); drafted the manuscript (DPP, BRS); reviewed the manuscript (DPP, AG, BRS); read and approved the final manuscript (DPP, AG, BRS).

Financial/Material Support: DPP's research on snakebite in Nepal was supported by the South Asian Clinical Toxicology Research Collaboration and NHMRC CRE APP1110343, Australia.

Disclosures: None. 


\section{References}

1. Rojnuckarin P, Intragumtornchai T, Sattapiboon R, Muanpasitporn C, Pakmanee N, Khow O, et al. The effects of green pit viper (Trimeresurus albolabris and Trimeresurus macrops) venom on the fibrinolytic system in human. Toxicon. 1999;37(5):743-55.

2. Hutton R, Looareesuwan S, Ho M, Silamut K, Chanthavanich $\mathrm{P}$, Karbwang J, et al. Arboreal green pit vipers (Genus Trimeresurus) of South-East Asia: bites by T. albolabris and $T$. macrops in Thailand and a review of the literature. Trans $R$ Soc Trop Med Hyg. 1990;84(6):866-74.

3. Mitrakul C. Clinical features of viper bites in 72 Thai children. Southeast Asian J Trop Med Public Health. 1982;13 (4):628-36.

4. Sarmin S, Amin MR, Al-Mamun H, Rahman R, Faiz MA. Clinical aspects of green pit viper bites in Bangladesh: a study on 40 patients. Asia Pacific J Med Toxicol. 2013;2(3):96-100.

5. Namal Rathnayaka RMMK, Ranathunga PEAN, Kularatne SAM. Epidemiology and clinical features of Green Pit Viper (Trimeresurus trigonocephalus) envenoming in Sri Lanka. Toxicon. 2017;137(Supplement C):99-105.

6. Namal Rathnayaka RMMK, Kularatne SAM, Ranathunga PEAN. Coagulopathy and extensive local swelling following green pit viper (Trimeresurus trigonocephalus) envenoming in Sri Lanka. Toxicon. 2017;129 (Supplement C):95-9.

7. Isbister GK. Snakebite doesn't cause disseminated intravascular coagulation: coagulopathy and thrombotic microangiopathy in snake envenoming. Semin Thromb Hemost. 2010;36(4):444-51.

8. Uetz P, Freed P, Jirí H. Global reptile species checklists as Excel spreadsheets; 2018. Available from: http://www.reptile-database.org. Accessed September 2, 2018.

9. Smith MA. On the collection of amphibians and reptiles from Nepal. Ann Mag Nat Hist Zool Bot Geol. 1951;12(4):726-8.

10. Nanhoe LMR, Ouboter PE. The distribution of reptiles and amphibians in the Annapurna-Dhaulagiri region (Nepal). Zool Verh (Leiden). 1987;240(1):1-100.

11. Fleming RL, Fleming RL. Some snakes from Nepal. J Bombay Nat Hist Soc. 1973;70(3):426-37.

12. Rai KR. Environmental Impact Systematics and Distribution of Herpetofauna from East Nepal. $\mathrm{PhD}$ thesis. Kritipur, Kathmandu, Nepal: Central Department of Zoology, Tribhuvan University; 2003.

13. Pandey DP. Snakes in the vicinity of Chitwan National Park, Nepal. Herpetol Conserv Biol. 2012;7(1):46-57.

14. Pandey DP. Venomous Snakes of Medical Relevance in Nepal: Study on Species, Epidemiology of Snake Bite and Assessment of Risk Factors of Envenoming and Death, Frankfurt, Germany: J. W. Goethe University; 2015.

15. Swan LW, Leviton AE. The herpetology of Nepal: a history, checklist and zoogeographical analysis of the herpetofauna. Proc Calif Acad Sci. 1962;32(6):103-47.

16. Kramer E. Zur Schlangenfauna Nepals. Rev Suisse Zool. 1977;84(3):721-61.

17. Pandey DP, Sharma SK, Alirol E, Sharma CM, Thapa-Magar C, Goode M, et al. Medically relevant venomous snakes and their distribution in Nepal: a hospital based study [abstract].
In: Keyler DE, Sanchez EE, eds. Abstract from Venom Week VI. March 14-18, 2018. Kingsville, TX: Texas A\&M University; 2018:315-34. Toxicon. 2018;150:331.

18. Pandey DP, Jelic D, Sapkota S, Lama HM, Lama B, Pokharel K, et al. New records of snakes from Chitwan National Park and vicinity, Central Nepal. Herpetol Notes. 2018;11:679-96.

19. Pandey DP, Vohra R, Stalcup P, Shrestha BR. A season of snakebite envenomation: presentation patterns, timing of care, anti-venom use, and case fatality rates from a hospital of southcentral Nepal. J Venom Res. 2016;7:1-9.

20. Wallach V, Williams KL, Boundy J. Snakes of the World: a Catalogue of Living and Extinct Species. New York: CRC Press; 2014.

21. Faiz MA, Chowdhury SK, Hussain A. Snake bite in Chittagong and Cox's Bazar: a hospital based study. Bangladesh J Med. 1997;8:52-7.

22. Chan J, Kwok M, Cockram C, Permatilleke M. Blood coagulation abnormalities associated with envenoming by Trimeresurus albolabris in Hong Kong. Singapore Med J. 1993;34(2):145-7.

23. Chan TY, Chan JC, Tomlinson B, Critchley JA. Clinical features and hospital management of bites by the whitelipped green pit viper (Trimeresurus albolabris). Southeast Asian J Trop Med Public Health. 1993;24(4):772-5.

24. Cockram CS, Chan JCN, Chow KY. Bites by the whitelipped pit viper (Trimeresurus albolabris) and other species in Hong Kong-a survey of 4 years experience at the Prince of Wales Hospital. J Trop Med Hyg. 1990;93(2):79-86.

25. Suankratay C, Wilde H, Nunthapisud P, Khantipong M. Tetanus after white-lipped green pit viper (Trimeresurus albolabris) bite. Wilderness Environ Med. 2002;13 (4):256-61.

26. Warrell DA. Clinical toxicology of snakebite in Asia. In: Meier J, White J, eds. Handbook of Clinical Toxicology of Animal Venoms and Poisons. New York: CRC Press; 1995:493-594. preliminary pages 16 and 752.

27. Yang JY, Hui H, Lee AC. Severe coagulopathy associated with white-lipped green pit viper bite. Hong Kong Med J. 2007;13(5):392-5.

28. Chan TYK, Hung LK. Digital gangrene following a green pit viper bite. Southeast Asian J Trop Med Public Health. 2010;41(1):192-4.

29. Sharma SK, Koirala S, Dahal G, Sah C. Clinico-epidemiological features of snakebite: a study from eastern Nepal. Trop Doct. 2004;34(1):20-2.

30. Sharma SK, Kuch U, Höde P, Bruhse L, Pandey DP, Ghimire A, et al. Use of molecular diagnostic tools for the identification of species responsible for snakebite in Nepal: a pilot study. PLoS Negl Trop Dis. 2016;10(4) e0004620.

31. Kabisch K. Family Viperidae (vipers). In: Schleich HH, Kästle W, eds. Amphibians and Reptiles of Nepal: Biology, Systematics, Field Guide. Ruggell, Germany: A.R.G. Gantner Verlag Kommanditgesellschaft; 2002:1006-42.

32. Whitaker R, Captain A. Snakes of India: the Field Guide. 1st ed. Chengalpattu, Chennai: Draco Books; 2004. 
33. Tan NH, Fung SY, Yap YHY. Isolation and characterization of the thrombin-like enzyme from Cryptelytrops albolabris (white-lipped tree viper) venom. Comp Biochem Physiol B Biochem Mol Biol. 2012;161(1):79-85.

34. Dumavibhat B, Visudhiphan S, Malasit P. Severe cases of green pit viper snake venom poisoning. J Med Assoc Thai. 1989;72(10):593-6.

35. Maduwage K, Isbister GK. Current treatment for venominduced consumption coagulopathy resulting from snakebite. PLoS Negl Trop Dis. 2014;8(10):e3220.

36. Wiwanitkit V. A review of the hematologic effects of green pit viper venom. J Toxicol Toxin Rev. 2004;23(1):105-10.

37. Suen PY. Bamboo snake (Trimeresurus albolabris) bite in Hong Kong and its prognostic factors for local complications with surgical intervention, coagulopathy and thrombocytopenia. Hong Kong J Emerg Med. 2017;24(2):79-84.

38. Soogarun S, Wiwanitkit V, Suwansaksri J. A trend of platelet indices in patients with green pit viper toxin. Clin Appl Thromb Hemost. 2003;9(4):337-9.

39. Isbister G, Maduwage K, Page C. Antivenom cross neutralisation in a suspected Asian pit viper envenoming causing severe coagulopathy. Toxicon. 2014;90:286-90.

40. Visudhiphan S, Dumavibhat B, Trishnananda M. Prolonged defibrinauon syndrome after green pit viper bite with persisting venom activity in patient's blood. Am J Clin Pathol. 1981;75(1):65-9.

41. World Health Organization. Guidelines for the Management of Snakebites. 2nd ed. New Delhi: World Health Organization; 2016.

42. Greene S, Galdamez LA, Tomasheski R. White-lipped tree viper (Cryptelytrops albolabris) envenomation in an American viper keeper. J Emerg Med. 2017;53(6):e115-8.

43. Rojnuckarin P, Chanthawibun W, Noiphrom J, Pakmanee $\mathrm{N}$, Intragumtornchai T. A randomized, double-blind, placebo-controlled trial of antivenom for local effects of green pit viper bites. Trans R Soc Trop Med Hyg. 2006;100 (9):879-84.

44. Theakston R, Phillips R, Looareesuwan S, Echeverria P, Makin T, Warrell D. Bacteriological studies of the venom and mouth cavities of wild Malayan pit vipers (Calloselasma rhodostoma) in southern Thailand. Trans $R$ Soc Trop Med Hyg. 1990;84(6):875-9.

45. Chen CM, Wu KG, Chen CJ, Wang CM. Bacterial infection in association with snakebite: a 10-year experience in a northern Taiwan medical center. J Microbiol Immunol Infect. 2011;44(6):456-60.

46. Garg A, Sujatha S, Garg J, Acharya NS, Chandra Parija S. Wound infections secondary to snakebite. J Infect Dev Countries. 2009;3(3):221-3.

47. Kerrigan KR. Bacteriology of snakebite abscess. Trop Doct. 1992;22(4):158-60.

48. Jorge M, Malaque C, Ribeiro L, Fan HW, Cardoso JL, Nishioka SA, et al. Failure of chloramphenicol prophylaxis to reduce the frequency of abscess formation as a complication of envenoming by Bothrops snakes in Brazil: a double-blind randomized controlled trial. Trans $R$ Soc Trop Med Hyg. 2004;98(9):529-34.
49. Kerrigan KR, Mertz BL, Nelson SJ, Dye JD. Antibiotic prophylaxis for pit viper envenomation: prospective, controlled trial. World J Surg. 1997;21(4):369-73.

50. Burgess JL, Dart RC. Snake venom coagulopathy: use and abuse of blood products in the treatment of pit viper envenomation. Ann Emerg Med. 1991;20(7):795-801.

51. Rojnuckarin P, Banjongkit S, Chantawibun W, Akkawat B, Juntiang J, Noiphrom J, et al. Green pit viper (Trimeresurus albolabris and T. macrops) venom antigenaemia and kinetics in humans. Trop Doct. 2007;37(4):207-10.

52. Holla SK, Rao HA, Shenoy D, Boloor A, Boyanagari M. The role of fresh frozen plasma in reducing the volume of anti-snake venom in snakebite envenomation. Trop Doct. 2018;48(2):89-93.

53. Isbister G, Jayamanne S, Mohamed F, Dawson AH, Maduwage K, Gawarammana I, et al. A randomized controlled trial of fresh frozen plasma for coagulopathy in Russell's viper (Daboia russelii) envenoming. J Thromb Haemost. 2017;15(4):645-54.

54. Shrestha BR, Pandey DP, Acharya KP, Thapa-Magar C, Mohamed F, Isbister GK. Effective, polyvalent, affordable antivenom needed to treat snakebite in Nepal. Bull World Health Organ. 2017;95(10):718-9.

55. Chanhome L, Khow O, Omori-Satoh T, Sitprija V. Capacity of Thai green pit viper antivenom to neutralize the venoms of Thai Trimeresurus snakes and comparison of biological activities of these venoms. J Nat Toxins. 2002;11(3):251-9.

56. Pakmanee N, Khow O, Wongtongkam N, Omori-Satoh T, Sitprija V. Efficacy and cross reactivity of Thai green pit viper antivenom among venoms of Trimeresurus species in Thailand and Japan. J Nat Toxins. 1998;7(2):173-83.

57. Leong PK, Tan CH, Sim SM, Fung SY, Sumana K, Sitprija $\mathrm{V}$, et al. Cross neutralization of common Southeast Asian viperid venoms by a Thai polyvalent snake antivenom (Hemato Polyvalent Snake Antivenom). Acta Trop. 2014;132:7-14.

58. Nuchprayoon I, Pongpan C, Sripaiboonkij N. The role of prednisolone in reducing limb oedema in children bitten by green pit vipers: a randomized, controlled trial. Ann Trop Med Parasitol. 2008;102(7):643-9.

59. Sitprija V. Snakebite nephropathy. Nephrology. 2006; 11(5):442-8.

60. Kanjanabuch T, Sitprija V. Snakebite nephrotoxicity in Asia. Semin Nephrol. 2008;28(4):363-72.

61. Pandey DP, Subedi Pandey G, Devkota K, Goode M. Public perceptions of snakes and snakebite management: implications for conservation and human health in southern Nepal. J Ethnobiol Ethnomed. 2016;12(1):1-25.

62. Tun-Pe, Aye-Aye-Myint, Khin-Ei-Han, Thi-Ha, Tin-NuSwe. Local compression pads as a first aid measure for victims of bites by Russell's viper (Daboia russelii siamensis) in Myanmar. Trans R Soc Trop Med Hyg. 1995;89(3):293-5.

63. Lavonas EJ, Ruha AM, Banner W, Bebarta V, Bernstein JN, Bush SP, et al. Unified treatment algorithm for the management of crotaline snakebite in the United States: results of an evidence-informed consensus workshop. BMC Emerg Med. 2011;11:2. 